\title{
Acclimatization Study for Biohydrogen Production from Palm Oil Mill Effluent (POME) in Continuous-flow System
}

\author{
N. Idris ${ }^{1}, N . A$. Lutpi ${ }^{1, *}, Y . S$. Wong ${ }^{1}$, and T.N. Tengku Izhar ${ }^{1}$ \\ ${ }^{1}$ School of Environmental Engineering, Universiti Malaysia Perlis, 02600, Arau, Perlis, Malaysia
}

\begin{abstract}
This research aims to study the acclimatization phase for biohydrogen production from palm oil mill effluent (POME) by adapting the microorganism to the new environment in continuous-flow system of thermophilic bioreactor. The thermophilic fermentation was continuously loaded with $0.4 \mathrm{~L} /$ day of raw POME for 35 days to acclimatize the microorganism until a steady state of biohydrogen production was obtained. The significance effect of acclimatization phase on parameter such as $\mathrm{pH}$, microbial growth, chemical oxygen demand (COD), and alkalinity were also studied besides the production of biogas. This study had found that the thermophilic bioreactor reach its steady state with 1960 $\mathrm{mL} / \mathrm{d}$ of biogas produced, which consist of $894 \mathrm{ppm}$ of hydrogen composition.
\end{abstract}

\section{Introduction}

Dependency on fossil fuel to fulfil energy demands has become a big issue for developing countries. Due to that reason, the development of alternative energy source has become matter of urgency. Hydrogen is a one of the promising energy supply to replace the dependency on fossil fuels. According to $\mathrm{Ni}$ et al., (2006) [1] energy crisis and environmental sustainability are two important issues that need to take into consideration for a global sustainable development. Hydrogen is well known as clean energy carrier since it is renewable energy source with carbon free [2]. No residue that would adverse the environment or human life when hydrogen energy is burned [3]. Hydrogen also contributes substantially to the devaluation of greenhouse gas emissions as well as its might be considered as clean and climate neutral energy system [4]. Besides, hydrogen need a helterskelter vitality yield about $122 \mathrm{~kJ} / \mathrm{g}$, which will be 2.75 times greater over hydrocarbon fills [5]. Various processes are being used to produce hydrogen gas, including photo fermentation, dark fermentation, photolysis and electrolysis of water. Among all, the most feasible processes are to be dark fermentation [6].

Dark fermentation is the fermentative conversion of organic substrate to hydrogen during adaptation of organic substances into volatile fatty acids and mainly involving acidogenic bacteria [7]. Microorganism in fermentation process hydrolyze organic substance into monomers and reduce molecular weight of organic acids by acidogenic

* Corresponding author: nabilah@unimap.edu.my 
bacteria [8]. Application of wastewater as a potential substrate for biohydrogen production has been major interest in recent years especially in the dark fermentation process. As for this study, palm oil mill effluent has been chosen as the wastewater source to produce biohydrogen.

Malaysia is the largest producer and exporter of crude palm oil (CPO). The production of crude palm oil reached 29 million tonnes in the year 2015 from 28 million tonnes in the year 2014 [9]. Palm oil is produced using huge amount of water in mills where oil is extracted from the palm fruits. During the eradication of crude palm oil from the fruits, $50 \%$ of the water results in palm oil mill effluent (POME) [10]. This huge quantity of POME that contains high concentration of chemical oxygen demand (COD), biochemical oxygen demand (BOD), total nitrogen, total phosphorus, oil and grease, and total solids were produced and accompanied with the production of crude palm oil [11]. Therefore, this study will focus on the characteristic study of POME itself and the acclimatization phase of dark fermentation for biohydrogen production in thermophilic bioreactor.

\section{Materials and method}

\subsection{Wastewater source and characterization}

This research project was conducted by using palm oil mill effluent (POME) that was obtained from Malpom Industries Sdn Bhd, Sungai Bakap, Pulau Pinang. The POME wastewater was collected from the cooling pond whereby it takes place before it was discharge for further treatment. The characteristics of raw POME and anaerobic sludge were also being studied based on various parameters such as; $\mathrm{pH}$, temperature, total solid (TS), total volatile solid (TVS), mixed liquor suspended solid (MLSS), mixed liquor volatile suspended solid (MLVSS), chemical oxygen demand (COD), biochemical oxygen demand (BOD), alkalinity, total carbohydrate (TC) and total volatile fatty acid (TVFA) [12].

\subsection{Acclimatization study}

In this study, substrate that was used for fermentation in bioreactor start-up was taken from anaerobic pond treatment plant. About 14 liters of the anaerobic digested wastewater was used for the start-up and acclimatization. This acclimatization phase was continued for about 35 days to allow microorganisms present in the mixed liquor perfectly acclimatized to the new environment and reached a steady state condition before proceed to the next phase of research studies. The $\mathrm{pH}$ of the wastewater was adjusted to the range of $\mathrm{pH} 6 \pm 0.5$ to promote the production of biohydrogen. The schematic diagram of the thermophilic bioreactor is shown in Fig. 1.

\subsection{Analysis procedure}

The treated effluents were analyzed with the same parameter as in characteristic study, while the biogas composition that were collected from tedlar bag will be analyzed after every 24 hours of fermentation. The production of hydrogen, carbon dioxide, oxygen and methane will be measured using Gas Analyzer (biogas 5000 standard) Model GA 5000. 


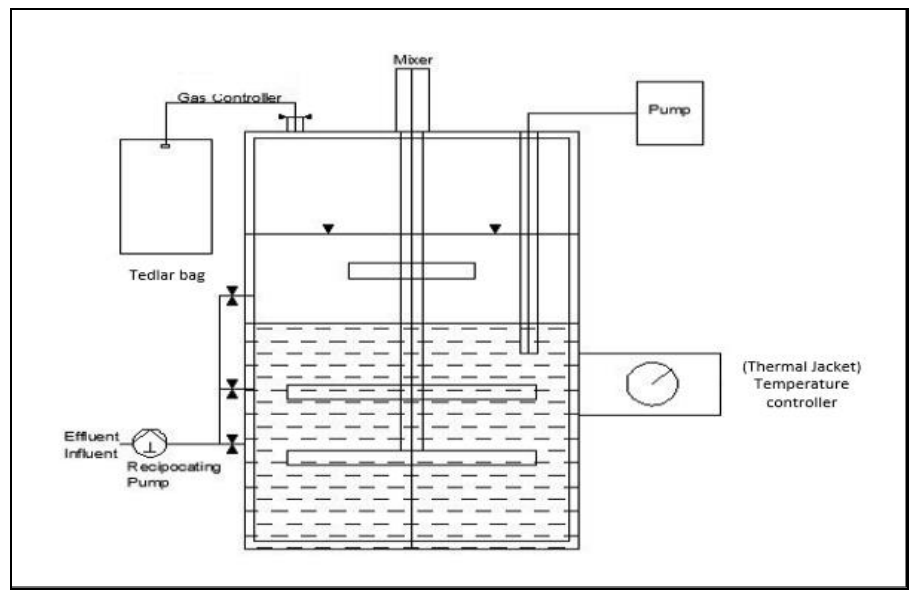

Fig. 1. Schematic diagram of experimental set-up of thermophilic bioreactor.

\section{Results and discussions}

\subsection{Wastewater characteristic}

Table 1 indicates that the BOD and COD of both raw POME and anaerobic sludge are extremely high. When POME is released into water resources, it can pollute the water supply. According to Cheng et al., (2015) [13] COD concentration is within the range of $45,000 \mathrm{mg} / \mathrm{L}$ to $65,000 \mathrm{mg} / \mathrm{L}$ while $\mathrm{BOD}_{5}$ is about $18,000 \mathrm{mg} / \mathrm{L}$ to $48,000 \mathrm{mg} / \mathrm{L}$. Furthermore, high value of suspended solids will lead to nasty odor and may cause epidemic. POME has high value of turbidity due to many organic compounds that not dissolved before the treatment.

Table 1. Wastewater characteristic of raw POME and anaerobic sludge.

\begin{tabular}{|c|c|c|}
\hline & Raw POME & Anaerobic sludge \\
\hline $\mathrm{pH}$ & 4.42 & 4.91 \\
\hline Temperature & $56^{\circ} \mathrm{C}$ & $32{ }^{\circ} \mathrm{C}$ \\
\hline Total solid (TS) & $33930 \mathrm{mg} / \mathrm{L}$ & $29015 \mathrm{mg} / \mathrm{L}$ \\
\hline Total volatile solid (TVS) & $27260 \mathrm{mg} / \mathrm{L}$ & $24615 \mathrm{mg} / \mathrm{L}$ \\
\hline $\begin{array}{l}\text { Mixed liquor suspended solid } \\
\text { (MLSS) }\end{array}$ & $56800 \mathrm{mg} / \mathrm{L}$ & $50650 \mathrm{mg} / \mathrm{L}$ \\
\hline $\begin{array}{l}\text { Mixed liquor volatile suspended } \\
\text { solid (MLVSS) }\end{array}$ & $54750 \mathrm{mg} / \mathrm{L}$ & $48600 \mathrm{mg} / \mathrm{L}$ \\
\hline Chemical oxygen demand (COD) & $86333 \mathrm{mg} / \mathrm{L}$ & $82066 \mathrm{mg} / \mathrm{L}$ \\
\hline $\begin{array}{l}\text { Biochemical oxygen demand } \\
\text { (BOD) }\end{array}$ & $34300 \mathrm{mg} / \mathrm{L}$ & $34000 \mathrm{mg} / \mathrm{L}$ \\
\hline Alkalinity & - & $2569 \mathrm{mg} / \mathrm{L}$ \\
\hline Total carbohydrate (TC) & $12.74 \mathrm{~g} / \mathrm{L}$ & $6.40 \mathrm{~g} / \mathrm{L}$ \\
\hline Volatile acidity (TVFA) & $\begin{array}{l}11542.86 \mathrm{mg} \\
\mathrm{CH}_{3} \mathrm{COOH} / \mathrm{L} \\
\end{array}$ & $\begin{array}{r}7257.14 \mathrm{mg} \\
\mathrm{CH}_{3} \mathrm{COOH} / \mathrm{L} \\
\end{array}$ \\
\hline
\end{tabular}




\subsection{Analysis procedure}

\subsection{1 $\mathrm{pH}$ variation during acclimatization phase}

The $\mathrm{pH}$ variations of this fermentation during acclimatization phase are presented in Fig. 2. The initial $\mathrm{pH}$ is 5.71 with $0.4 \mathrm{~L}$ /day of raw POME loaded every day for 35 days. According to Gonzalez et al., (2001) [14] in acclimatization phase, loading rate should be low to avoid drawback on the system. As shown Fig. 2, pH decrease from 5.71 to 5.59 between day 1 to day 7 . This is mostly due to increase of fatty acid concentration that clearly explained acidogenesis phase is occurred. Then, from day 8 to day $16, \mathrm{pH}$ reading fluctuated within range of 5.61 to 5.63. But from day 17 until day $35, \mathrm{pH}$ variation reached its stability of the anaerobic digestion process within range of 5.67 to 5.65.

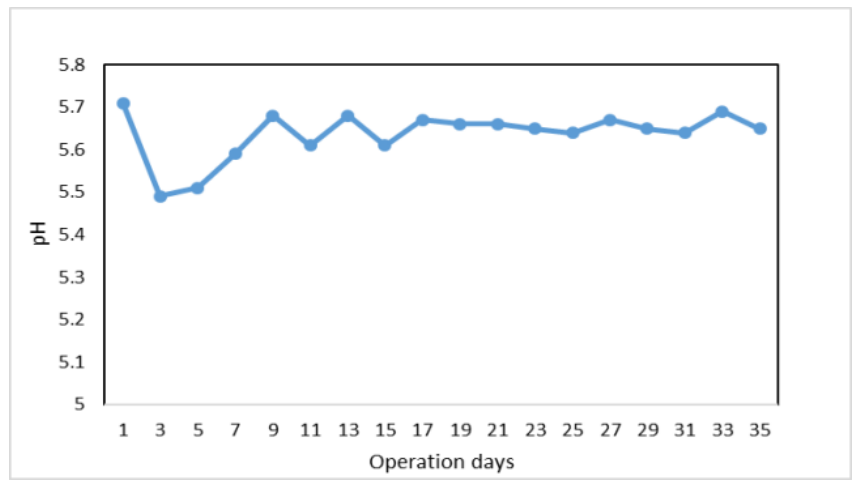

Fig. 2. $\mathrm{pH}$ variation during acclimatization phase.

\subsubsection{Microbial growth variations during acclimatization phase}

During acclimatization phase, microbial growth is referred as mixed liquor volatile suspended solid (MLVSS). Mixed liquor suspended solid (MLSS) was also measured as fraction ratio between MLVSS and MLSS. Commonly, the MLVSS used as indicator of the amount of organic matter contained in the sludge. Therefore, the desolation of MLVSS in sludge stabilization process can be used to determine the effectiveness of sludge stabilization process to the organic component in the sludge [15]. The microbial growth variations during acclimatization phase are shown in Fig. 3. At the beginning of acclimatization phase, the MLVSS started to increase gradually from $2550 \mathrm{mg} / \mathrm{L}$ to 8750 $\mathrm{mg} / \mathrm{L}$ from day 1 until day 6 . Then, the MLVSS fluctuated between $8500 \mathrm{mg} / \mathrm{L}$ and 12800 $\mathrm{mg} / \mathrm{L}$ for the next 12 days. At this phase, the colony of acidogenic bacteria was more than methanogenic bacteria to convert raw waste into organic acids, carbon dioxide and hydrogen gas [16]. Finally, biomass regained its stability from day 19 to day 35 with MLVSS reading is within $13350 \mathrm{mg} / \mathrm{L}$ and $13900 \mathrm{mg} / \mathrm{L}$. 


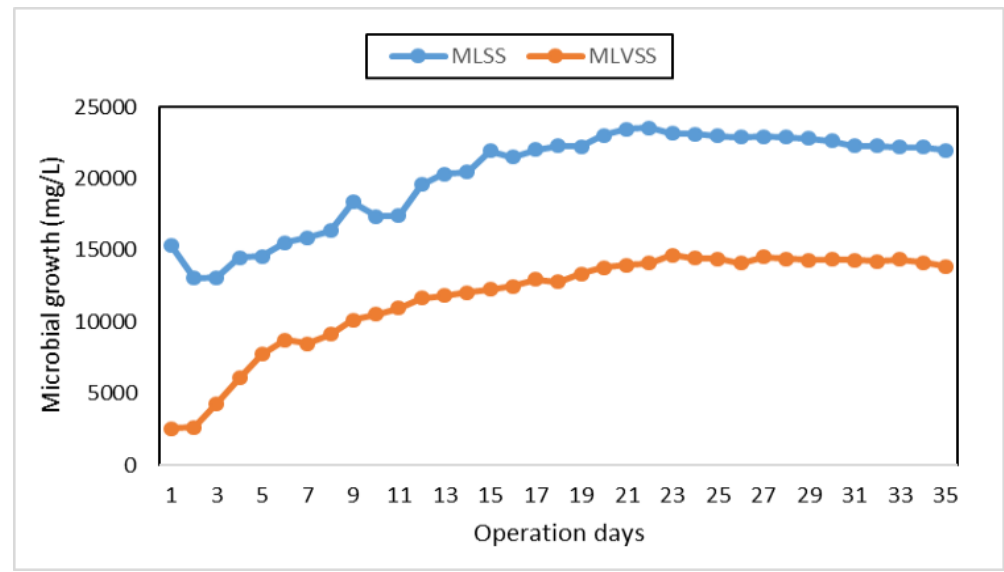

Fig. 3. Microbial growth during acclimatization phase.

\subsubsection{COD variations during acclimatization phase}

Fig. 4 shows the performance of bioreactor for Total COD (TCOD) and Soluble COD (SCOD) during acclimatization phase. TCOD represent the total COD in the bioreactor while SCOD represent the soluble (suspended of effluent) in the bioreactor. COD variations is important to evaluate microorganism activities toward environmental changes during acclimatization phase. Removal efficiency of TCOD and SCOD were calculated as the difference between initial and final concentrations inside the bioreactor. Removal efficiency for TCOD is $14.8 \%$ while for SCOD is $22.6 \%$. This is proved that this bioreactor not only focusing on producing biogas especially hydrogen, but also decrease the COD value itself. Based on Figure 4, TCOD reading fluctuated from day 1 until day 15 which is from 70900 $\mathrm{mg} / \mathrm{L}$ to $78600 \mathrm{mg} / \mathrm{L}$. After that, from day 16 until day 35, TCOD reading reached its stability as microbial growth in the bioreactor are adapting to the new environment. The pattern of SCOD reading almost same with TCOD as its reach their stability on day 16 . COD reading for both soluble and total reach stability as the bacteria already acclimatized themselves to the new environment through increasing the number of active microorganism [17].

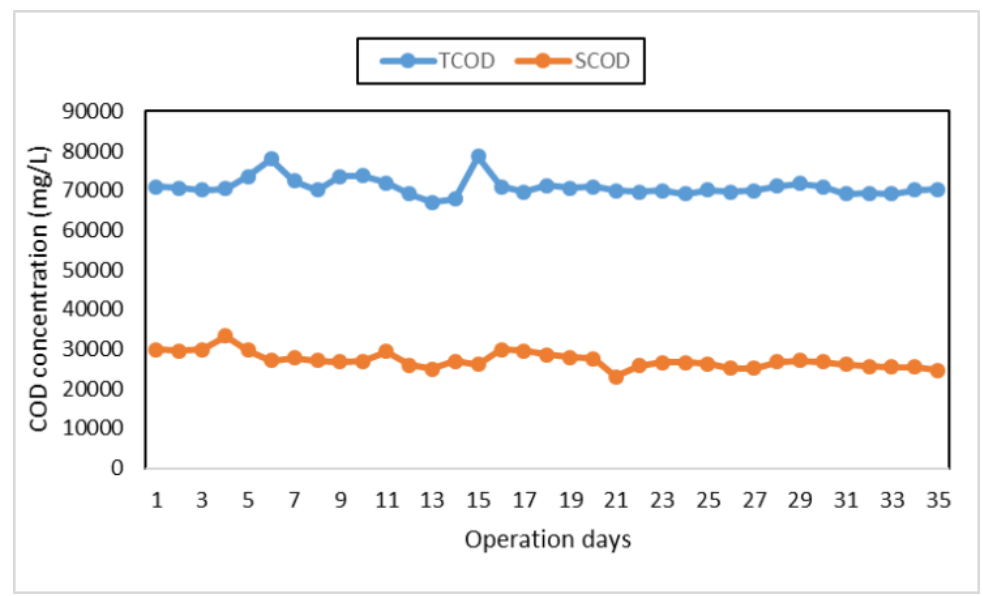

Fig. 4. TCOD and SCOD concentration of effluent during acclimatization phase. 


\subsubsection{Alkalinity variations during acclimatization phase}

Fig. 5 describes the alkalinity concentration of mixed effluent during acclimatization phase. Initial concentration of alkalinity dropped from day 1 to day 3 around $5790 \mathrm{mg} / \mathrm{L}$ to 2170 $\mathrm{mg} / \mathrm{L}$. After that, from day 4 to day 11 , it started increasing slightly from $3140 \mathrm{mg} / \mathrm{L}$ to $5470 \mathrm{mg} / \mathrm{L}$ for 8 days. This occurred due to the increasing of buffering capacity of the bioreactor impact from volatile fatty acid (VFA) that started to accumulate due to slow conversion of VFA that caused of the population of biomass increased [18]. In addition, the alkalinity of wastewater will increase as increasing in biomass concentration in wastewater [19]. For the next 24 days, the alkalinity remains constant around $5980 \mathrm{mg} / \mathrm{L}$ to $6010 \mathrm{mg} / \mathrm{L}$ due to it reached the steady state condition since the biomass growth remains constant.

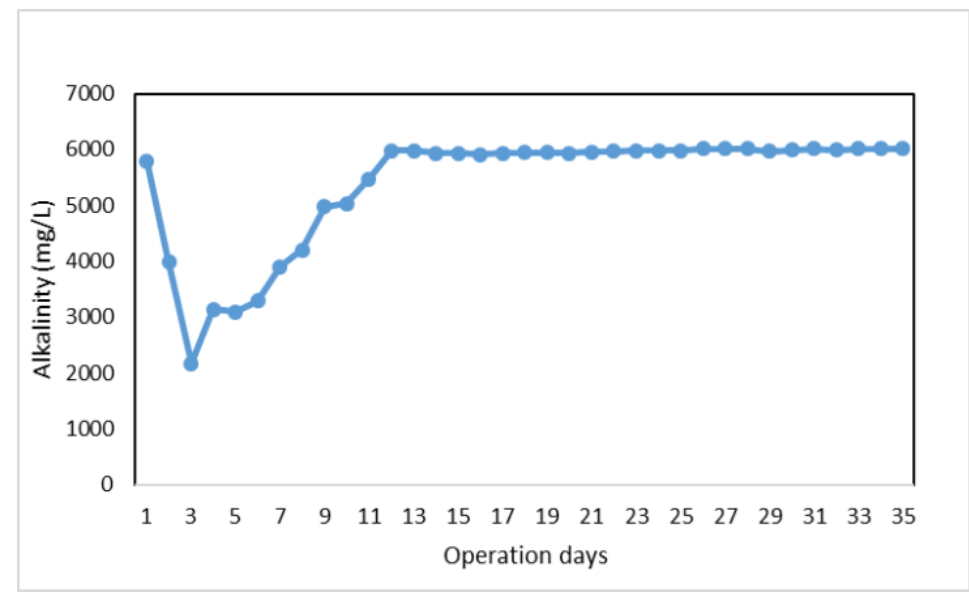

Fig. 5. Alkalinity variations during acclimatization phase.

\subsubsection{Biogas variations during acclimatization phase}

Biogas performance was also monitored every day at this acclimatization phase. Based on Fig. 6, the initial volume of biogas in bioreactor is $900 \mathrm{~mL}$ for day 1 . However, the biogas started to increase gradually from $900 \mathrm{~mL}$ to $1910 \mathrm{~mL}$ in day 11. Then, it sustained its stability from day 12 to day 35 which from $1900 \mathrm{~mL}$ to $1950 \mathrm{~mL}$. Once this acclimatization phase had achieved its stability, the biogas production is around $1960 \mathrm{~mL} /$ day. Hydrogen gas composition by using Gas Analyzer (biogas 5000 standard) Model GA 5000 was around 827 to 894 ppm once it reaches its steady state stating from day 11 . Hydrogen gas reading from gas analyzer is shown in Fig. 7 from day 1 until day 35 of acclimatization process. 


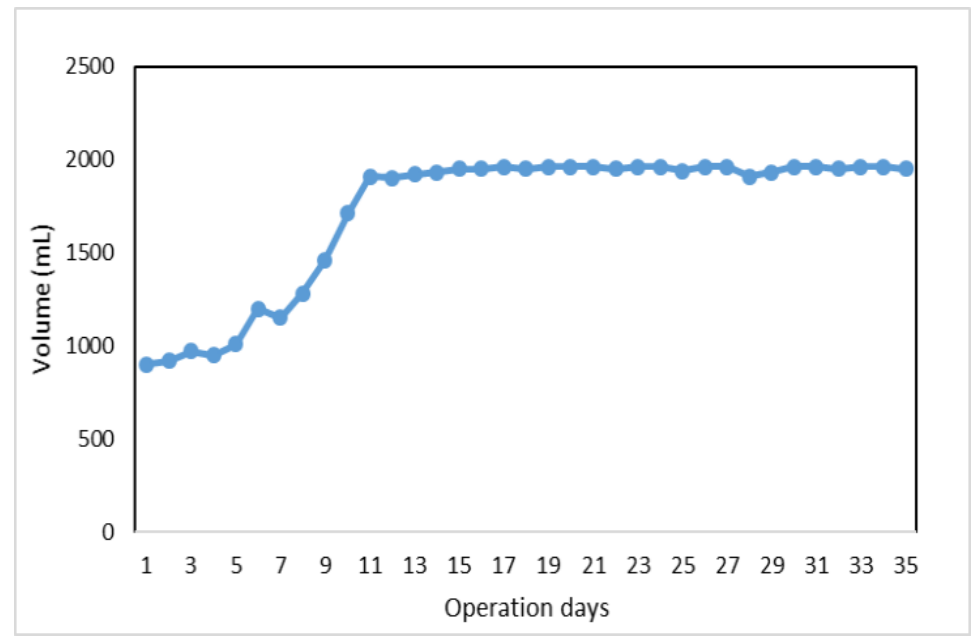

Fig. 6. Biogas variations during acclimatization phase.

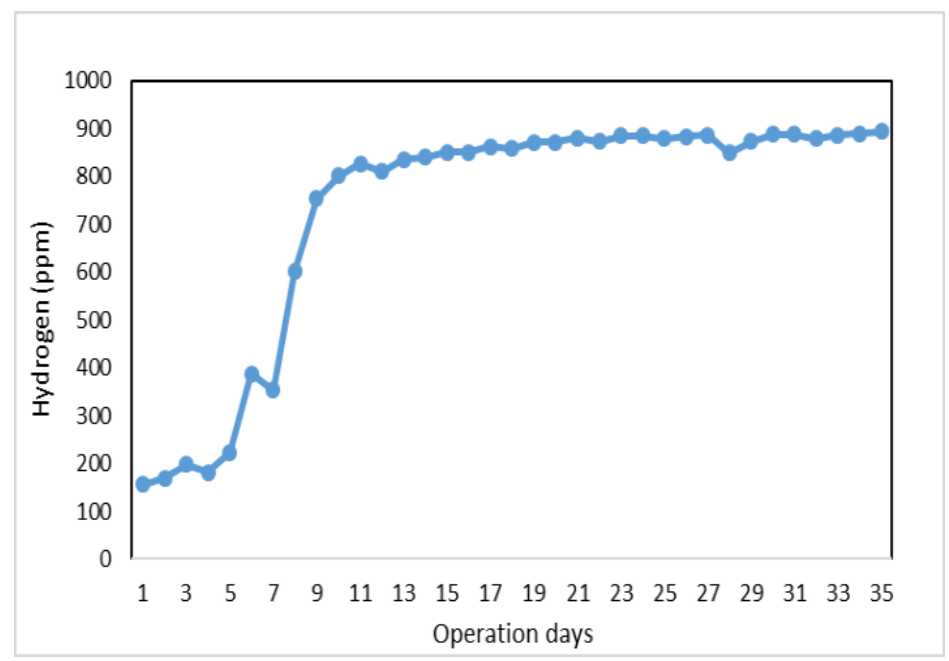

Fig. 7. Production of hydrogen gas reading based on daily intake.

\section{Conclusions}

In this research, the acclimatization phase of biohydrogen production through dark fermentation has been studied and achieved its stability in continuous-flow system. From the liquid analysis and biogas variations, it showed that these treated effluents are adapting to the new environment in the bioreactor. There is no report from previous study that clarify how long is required to acclimatize the microorganism to adapt to the new environment. However, in this study, 35 days is needed to reach its stability, with a maximum of 1960 $\mathrm{mL} / \mathrm{d}$ of biogas is produced and $894 \mathrm{ppm}$ of hydrogen composition.

This research is fully supported by FRGS grant (FRGS No: 9003-00511). The authors fully acknowledged Ministry of Higher Education (MOHE) and Universiti Malaysia Perlis (UniMAP) for the approved fund, which makes this important research viable and effective. 


\section{References}

1. M. Ni, D. Y. C. Leung, M. K. H. Leung, K. Sumathy, Fuel Process. Technol. 87, 461-72 (2006)

2. S. Dunn, Int. J. Hydrogen Energy. 27, 235-264 (2002)

3. S. Apak, E. Atay, G. Tuncer, Int. J. Hydrogen Energy. 42, 2446-2452 (2017)

4. S. M. Kotay, D. Das, Int. J. Hydrogen Energy. 33, 258-63 (2008)

5. I. K. Kapdan, F. Kargi, Enzyme Microb. Technol. 38, 569-582 (2006)

6. K. Nath, D. Das, Int. J. Hydrogen Energy. 34, 7497-7501 (2009)

7. C. Chen, M. Yang, K. Yeh, C. Liu, J. Chang, Int. J. Hydrogen Energy. 33, 4755-4762 (2008)

8. C. Cote, D. I. Masse, S. Quessy, Bioresour Technol. 97, 686-691 (2006)

9. Malaysia Palm Oil Board, http://www.mpob.gov.my/ accessed on $17^{\text {th }}$ November 2017.

10. Okwute, L. Ojonoma, Isu, R. Nnennaya, African Journal of Agricultural Research. 2, 656-662 (2007)

11. S. Dong, Y. Pi, Q. Li, L. Hu, Y. Li, X. Han, J. Wang, J. Sun, J. Alloys Compd. 663, 1-9 (2016)

12. APHA. Standard methods for the Examination of Water and Wastewater. Washington DC (1992)

13. C. K. Cheng, M. R. Derahman, M. R. Khan, J. Env. Chem. Eng. 3, 261-270 (2015)

14. A. C. Gonzalez, M. E. Poy, C. Duran-de-Bazua, Anaerobe Biotech. J. 7, 143149 (2001)

15. C. Arnaiz, J. C. Gutierrez, J. Lebrato, Bioresour Technol. 97, 1179-1184 (2006)

16. M. Chong, V. Sabaratnam, Y. Shirai, M. A. Hassan, Int. J. Hydrogen Energy. 34, 3277-3287 (2006)

17. G. Gonzalez, H. Urrutia, M. Roeckel, E. Aspe, Chem. Technol. Biotechno. J. 80, 151-157 (2015)

18. S. Yacob, Y. Shirai, M. A. Hassan, M. Wakisaka, S. Subash, Process Biochem. 41, 962-964 (2006)

19. Metcalf \& Eddy, F. L. Burton, H. D. Stensel, G. Tchobanoglous, G. (2003)

20. Wastewater engineering: treatment and reuse. McGraw Hill 